\author{
DEPARTMENT OF THE INTERIOR \\ UNITED STATES GEOLOGICAL SURVEY
}

\title{
AEROMAGNETIC MAP OF THE ONECO QUADRANGLE CONNECTICUT AND RHODE ISLAND
}

By

G. R. Boynton and C. W. Smith

\author{
GEOPHYSICAL INVESTIGATIONS \\ MAP GP-54:2
}

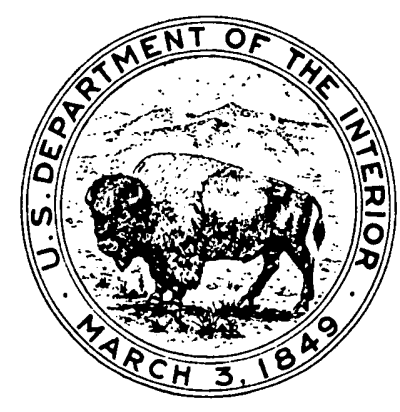

